\title{
Visualization of princess characters in the Wayang comics of Teguh Santosa for digital graphics development
}

\author{
M.I.P. Koesoemadinata \\ Telkom University, Bandung, Indonesia \\ A.Z. Mansoor \\ Institut Teknologi Bandung, Bandung, Indonesia
}

\begin{abstract}
Women's issues are frequently brought up within cultural studies and academic discourses in correlation with the patriarchal culture which is still embedded in traditional Javanese views. Issues that are rarely studied are women's portrayal in Indonesian comics, especially the wayang genre that refers to Javanese culture. Wayang art is significant to Javanese culture, along with its patriarchal ideology. By assumption, that ideology is also reflected in the wayang comics. Using descriptive qualitative analysis, preceded by aesthetical morphology, this paper discussed the way a wayang comic artist visualized princess characters. Teguh Santosa was chosen due to his reputation as an Indonesian comic maestro, along with his sensual visualization of women. Finally, the kind of sociocultural context with which Teguh perceived women, and the visual translation method he invented, was explored. This will complete understanding on Javanese wayang adaptations into comics and the possibility of it being realized in digital media.
\end{abstract}

Keywords: Teguh Santosa, Wayang comics, men, Javanese culture, visualization

\section{INTRODUCTION}

\subsection{Women issues in Javanese culture}

Most of Indonesian's cultural traditions have patriarchal tendencies, including Javanese culture. Javanese culture frequently puts women as secondary, unequal to men, although women are still regarded as having honorable values, such as fidelity, obedience, patience, and self-restraint. Those virtues are not only imposed on women of nobility, but also on peasants (Ariani 2016). A noble woman always try to bring happiness in her domestic life; there's a sort of self-identification, even a fusion, with her husband, where his happiness is also the wife's happiness. This assumption was so strong that all Javanese women try hard to make their husbands happy in many ways.

According to Franz Magnis-Suseno, Javanese women are women that follow Javanese traditions and culture in their daily lives. Their lives are much influenced by the culture that is inherent in their lives, especially the wayang culture with its various figures as a model. According to Javanese traditions, an ideal wife must have an attitude like the wayang characters of Kunti and Sinta who are devoted to their husbands, accept conditions as they are, and are willing to take part in unpleasant conditions, while reamining patient, loyal, modest, obedient, and skilled (Ariani 2016). Wayang art as an important part of Javanese culture certainly brings values and traits that are widely embraced and affect the lives of Javanese people, especially the lives of its women.

\subsection{Wayang comics and Teguh Santosa}

Wayang genre comics were born during the Indonesian Old Order period as an affirmation of national identity - as part of the regime's nationalist political campaign at that time, which 
was threatened by various Western cultural influences considered as Neo-colonialism and Neoimperialism. In the process, wayang comics became characteristic of Indonesian comics and were highly promoted for their contribution in introducing traditional culture to young urban people (Gunawan 2018). The notable wayang comic artists were John Lo, Ardisoma, and R.A. Kosasih. R.A. Kosasih is legendary and is referred to in many wayang comics afterward.

After R.A. Kosasih, there was Teguh Santosa who was the second person to successfully adapt the Mahabharata story into comic form completely and also had a significant impact in introducing wayang stories to younger generations. Teguh was born and raised in Malang, in the family of a ketoprak (Javanese traditional theater) director. So, he understood very well the nuances of Javanese customs in the wayang that also applied in ketoprak. From the early 1980s until the late 1990s, he created a lot of wayang comics, starting with bonus series on Ananda children's magazines, colored comic series published by Misurind and finally several comic strips in local newspapers (Koesoemadinata 2018).

Lately, Teguh's works have been reprinted by Galang Press publisher in Yogyakarta, including the Mahabharata and Bharatayudha series compilation from Ananda magazine (1983-1984) in 2015, and even made into an English version. In 2015, his biography was published in the form of an anthology written by several academics and comic practitioners, entitled Maestro of Darkness: Teguh Santosa, 1942-2000 published by Media Nusa Creative in Malang, which published its second printing in 2016. Various scholarly publications discussed his works from the perspective of humanism and pluralism, specific to the comic Sandhora by Aditya Nirwana and later developed into the book Menimbang Sandhora (Nirwana \& Ginting 2017; Nirwana 2018). Others specifically discussed his wayang comic, comparing his visual style with the latest wayang comic. Some discussed how Teguh adapted the Surakarta wayang kulit image as a reference (Koesoemadinata \& Aditya 2016; Koesoemadinata 2018). A Facebook group called Pustaka Teguh Santosa was created, dedicated to appreciate him and as a gathering place for his fans. All of these proved that Teguh has a significant role in the development of Indonesian comics.

Before the wayang genre, Teguh worked on a lot of comics. One distinctive feature of his comics, besides the dominance of his black blockings, is the graceful, sensual, and "submissive" portrayal of beautiful women. This can be seen from his legendary comic Sandhora, where the female protagonist was displayed in sensual poses. In general, all women in his comics were portrayed as beautiul and ideal stereotypes. The female figure was drawn with circular and pointed eyebrows, curved eyelashes, and a slightly square jaw. They are seen with closed eyelids, giving the impression of being "submissive" and sensual, referring to the female models of the 1960s or 1970s. This was not surprising because Teguh himself was said to be a fan of James Bond films that were a trend the time (Valiandra 2016).

The questions are as follows. How did Teguh Santosa describe the image of women in wayang genre comics? How did the portrayal of these female figures represent elements of Javanese culture? How did he translate and integrate these elements with his own distinctive visual style? What are the opportunities to be developed in digital media? The assumption is that Teguh comics certainly reflects a bit of Javanese culture, but how and to what extent?

\section{METHODS}

This paper is a study of art and culture, in the scope of visual arts, based on qualitative-descriptive research that contains interpretations. The object of research was visual artifacts and design works, namely wayang comics created by Teguh, specifically on the visual portrayals of female characters in general, which include several figures, such as Drupadi, Sumbadra, Srikandi, Banowati, and Arimbi. The discussion was not specifically on the visualization of one character by character, because the portrayal is relatively similar for all, except for the Arimbi figure. The adaptation and visual portrayal of female wayang characters in the Teguh puppet comic are the focus of the discussion, compared to the image of Javanese shadow puppets and the wayang wong costume assumed to be the main reference. The element analyzed was the visual style in the comic, which 
included the portrayal of anatomy and appearance, posture and gestures, hair, clothing, accessories, and others, as well as the position in the scene.

The main data samples as observed artifacts were: (1) Mahabharata \# 1-10 wayang comic series, published by Misurind (Midas Surya Grafindo) (1986-1988); and (2) Mahabharata comic series bonuses Ananda children's weekly magazine no.17-52 \& no. 06-47 (1983-1984), Kartini Magazine Publisher. Secondary data samples were graphic images of Surakarta wayang kulit from various printed sources such as the works of Hardjowirogo (1949) and Sudjarwo et al. (2010). The Surakarta wayang image was chosen as a comparison due to the information in the comic; Teguh mentioned Sedjarah Wajang Purwa by Hardjowirogo (1949) as the primary source together with comic works by R.A. Kosasih. Clearly, Teguh refers to the "iconography" of the wayang character in the book, which contains graphic images of the Surakarta wayang style.

The analysis method used was a modified version of Aesthetic Morphology and Art Criticism from Edmund Burke Feldman in Koesoemadinata \& Aditya (2016). The stages were: visual description, formal analysis, interpretation and evaluation. The visual description stage, combined with formal analysis, will describe in detail the elements of appearance and portrayal of selected objects. Visual analysis (a combination of stages 1 and 2) of the characters was specifically carried out on: (1) biological anatomy, in part or in whole, including appearance, gesture and body language; and (2) clothing including accessories and other attributes. This stage was an analysis of the internal aspects (intra-aesthetic), the studied visual artifact object, which is considered as 'text'. Next, was the interpretation stage, where the previous stage was compared to external aspects (extra-aesthetic) such as graphic images of the same wayang character. It was linked to sociocultural contexts such as Javanese wayang traditional narratives, Javanese traditional views, women's discourses, and influences of popular culture that are contemporary with Teguh. The evaluation stage tried to comprehend the context and reasons behind the visual adaptation carried out by Teguh. Here the studied object was appreciated further.

\section{THE PRINCESS CHARACTERS VISUALIZATION ANALYSIS AND DISCUSSIONS}

The female characters' portrayal in wayang comics (also called putri/princess) was the same as his other comics. The female figure is drawn with circular and pointed eyebrows, curved eyelashes, and slightly square jaw, smooth arm with curling fingers, often seen lowering the head with eyelids closed, giving rise to a "submissive" and sensual impression. Almost all female characters have this similarity whether it's Drupadi, Sumbadra, or others. Without captions, it would be difficult for readers to distinguish one female character from another (Figure 1).
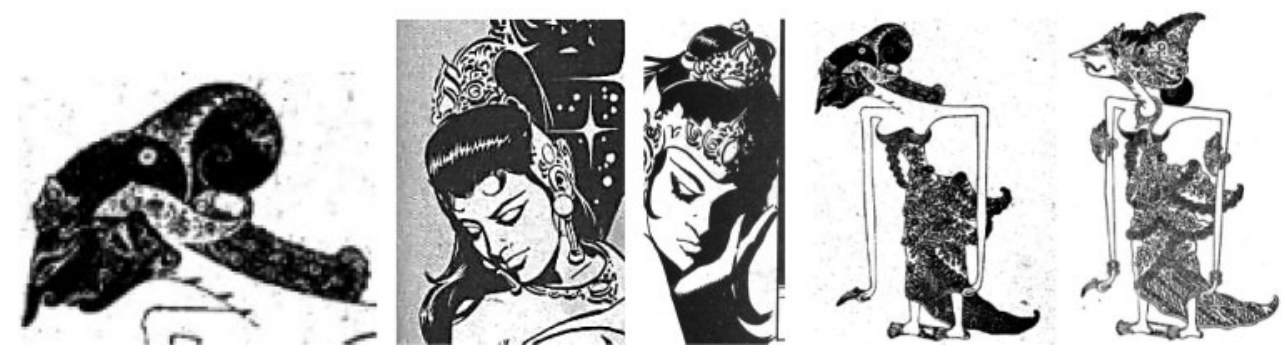

Figure 1. (From left to right) Lowering head position of princess characters in Javanese wayang images; Teguh's typical female visualization which also the same; various images of princess characters of Surakarta wayang style. Beside the head and shoulder positions, also worn costumes, all share the same facial visual pattern. (Sources: Hardjowirogo 1949; Sudjarwo et al. 2010; personal documentation).

This is in accordance with the visual aspect of the wayang puppet which indeed always repeats the same pattern, the same types of visual elements, with the same combination. The appearance 
of a princess figure imaged with the aim of accommodating the beautiful impression of a beautiful person. In Javanese shadow puppet art, the face of a princess is composed of anatomical elements such as jaitan eyes, a sharp nose, a salitan mouth, which are also equally used in the wayang facial imagery of satria characters, connoted to a handsome face. In general, the female figures (princesses) are each distinguished only from the worn objects, including head jewelry (crown, etc.) and hairdos (bun rivet, unraveled), then also clothing and other accessories.

Putri figures with idealized traits such as Sumbadra, Drupadi, Kunti, and so on usually have their heads lowered. This reflects submissive, patient, calm, and refined nature, which is usually found in the wayang class called putri luruh. Some female figures are portrayed as brave, agile, even temperamental, cunning and stubborn, like Srikandi and Banowati, called putri lanyap. In the puppet form, their heads are depicted more raised, but still portrayed as beautiful, seen from the same eye, nose, and mouth type (Figure 2).
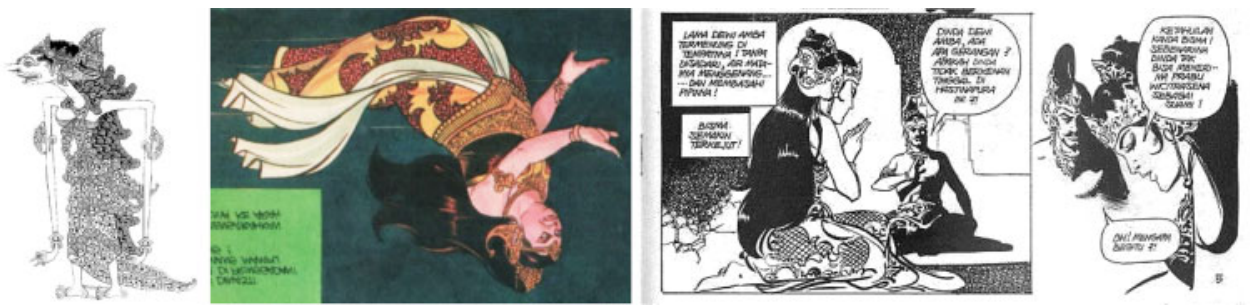

Figure 2. (from left to right) Graphic image of Arimbi puppet; depiction of Arimbi in Teguh's comic; a comic panel sequence which displays an interaction scene between a princess and a satria character. There seems to be a hierarchy between the two. (Sources: Sudjarwo et al. 2010; personal documentation).

An exception is found in the ogress princess' characters called raseksi, who has visual pattern different from human females. The body is slightly larger, with peten eyes, bentul nose, grinning mouth with fangs, and with the kithingan hand grip. Raseksi figures are often portrayed with such characteristics like bravery, straightforwardness, aggressive, even shameless, deceptive, and sexually proactive, is the opposition of the Putri luruh. Teguh visualized the raseksi's anatomy as neither ideal nor sensual as human princesses. The yes are rounder with very small pupils, a round face with a larger, plumper stature in comparison to human princesses, also the fangs in her mouth. This can be seen in the portrayal of Arimbi, the ogress mother of Gatotkaca.

Another improvisation made by Teguh besides the shift from symbolic wayang imagery to comic visual images (that tend to be naturalistic), was his characteristic of female's sensual impressions. This sensual portrayal is certainly difficult for us to consider as a direct inspiration from the wayang imageries which completely deviates from the real human form, but this is very clear when looking at Teguh's track record in his comic art career. Women's sensuality was clearly inspired by trending Western popular culture at the time (1970s), like his favorite James Bond films. The portrayals of the putri figures are hardly distinguished from each other (except for Arimbi). Facial portrayal with eyes closed or staring down, poses and postures that are bowed and "submissive" at the same time sensual, show the patriarchal ideology, placing women as such. This is indeed relevant to the wayang art's narrative itself, which contains patriarchal Javanese culture.

An interesting point that can be drawn from the analysis above is how Teguh has adapted the gestures of the female characters in the wayang scene into modern drawing styles according to his comic visual style. This becomes a system; a method of translating the gestures of female characters from traditional visual languages, which can be applied to modern media. These gestures can be used as the main gesture to represent women's gestures on social media or virtual character designs that represent wayang values based on the translation method used by Teguh.

According to the methods that Teguh developed, the development of female gestures visualization as graphic digital content are as follows: (a) face tilting and body gestures, face tilting and body gestures can emphasize the dignity of visualized females, whether she's a noble or commoner 
status, warrior or princess attitude, seductive or submissive character, and also active and passive interaction; and (b) camera angle and visual composition, how the creator positioned the character in a relationship with others may emphasize the social relationship in the narrative (whole story) or in moment opname (still frame visualization).

\section{CONCLUSIONS}

This paper discussed the matter briefly and only on surface. It only discussed a small part of the entire study and research on the works of Teguh Santosa, especially wayang comics, which is still ongoing. This study has no intention to disrespect and reduce the appreciation for the late Teguh Santosa as one of the Indonesian comics maestros. It's just showing and trying to understand that he was referring to the tradition as it is, with the intention of preserving culture. The traditional Javanese patriarchal culture inherent in the wayang story's narrative is reflected in the princess figures' portrayal in particular, seen from their position, posture, and gesture.

The courtesy of ideal women according to Javanese culture was strongly reflected and visualized within each scene of Teguh Santosa's wayang comic, and more. In addition to a more realistic approach, he also gave a sensual touch to the female characters that are unlikely to be found in the original Javanese wayang image, as a hallmark of his comic style. This showed a comic artist who lived at that time, with the spirit of the time and the cultural background of his family. Teguh was raised in a family of traditional Javanese ketoprak artists in the city of Malang, who also consumed modern (Western) popular culture that was trending. As a result, these different values were mixed in his works and became a unique artistic signature. However, beyond that, Teguh gave us a 'prototype' of visual translation method or system to adopt traditional Javanese wayang imageries into a modern visual representation that can be implemented in the digital media, yet still conveys the values of local wisdom.

\section{REFERENCES}

Ariani, I. 2016. Feminisme dalam Pergelaran Wayang Kulit Purwa Tokoh Dewi Shinta, Dewi Kunti, Dewi Srikandi. Jurnal Filsafat 26(2):272-290.

Gunawan, I. 2018. Cerita-Gambar, Highlight Perkembangan CerGam di Indonesia 1925-1985. Brosur Pameran Gudang Garam Art Award 2018: Dunia Komik “Bahasa Budaya Cerita Gambar”, xviii-xii. Jakarta: Galeri Nasional.

Hardjowirogo 1949. Sedjarah Wajang Purwa. Jakarta: Penerbit Balai Pustaka.

Koesoemadinata, M.I.P. 2018. Visual Adaptation of Wayang Characters in the Comic Arts of Teguh Santosa. Mudra Jurnal Seni Budaya 33(3):401-408.

Koesoemadinata, M.I.P. and Aditya, D.K. 2016. Visualizations of Wayang Characters in Comics (Case Study: Bima and Arjuna Characters in the Arts of Ardisoma, Teguh Santosa and Is Yuniarto). Proceeding The 3rd International Conference on Creative Industries, Bandung Creative Movement (BCM) 2016:274-282.

Nirwana, A. 2018. Menimbang Sandhora: Telaah Komik Teguh Santosa. Malang: Ma Chung Press.

Nirwana, A. and Ginting, D. 2017. Nilai Kemanusiaan dalam Bingkai Pluralisme dan Multikulturalisme dalam Komik Sandhora (1970) Karya Teguh Santosa. Andharupa, Jurnal Desain Komunikasi Visual \& Multimedia 03(01):92-114.

Sudjarwo, H.S., Sumari, and Wiyono, U. 2010. Rupa \& Karakter Wayang Purwa: Dewa-RamayanaMahabharata. Jakarta: Kakilangit Kencana.

Valiandra, D. 2016. Mengintip Proses Kreatif Teguh Santosa. In Malik, A. and Jai, S. (eds), Maestro of Darkness: Teguh Santosa, 1942-2000: 3-5. Malang: Media Nusa Creative. 


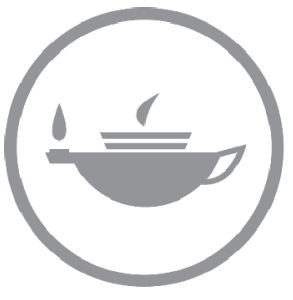

Taylor \& Francis Taylor \& Francis Group

http://taylorandfrancis.com 